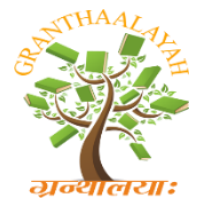

Science

\title{
MORINGA: ALTERNATIVE FOR THE FOOD SECURITY, CLIMATE RESILIENCE AND LIVELIHOOD IMPROVEMENT IN NEPAL
}

\author{
S. B. Thakur ${ }^{1}$, A. Bajagain ${ }^{2}$ \\ ${ }^{1,2}$ Climate Change Adaptation Project, Food and Agriculture Organization of United Nations, \\ Nepal
}

\begin{abstract}
Moringa oleifera L. is indigenous to northern foothills which includes Northern India, Pakistan and Nepal and genetic diversity is especially available in the Tarai region of Nepal including northern India. It's well climate stress adaptive nature, easy propagation, less input and intercultural operation requirement has proven to be boon in many ways. As it is the economical and reliable alternative for good nutrition, medicinal use, animal feed and fodder, plant supplement and soil reclamation, it can be touted as a miracle plant. Diverse form and edible utility of Moringa, helps for food and nutritional security for present and future. Likewise, carbon sinking attribute of its soft wood can be pivotal for curbing global warming and climate change. Moringa can thus help to create a well-nourished, healthy individual with happy family engaged in agriculture and agro-forestry blessed with good return and livelihood improvement. This review provides a brief overview about multipurpose use of Moringa and its implication to curb impacts on climate change, ensure food and nutrition security and sustain livelihood.
\end{abstract}

Keywords: Climate Change; Food Security; Livelihood; Moringa; Nutrition and Resilient.

Cite This Article: S. B. Thakur, and A. Bajagain. (2020). "MORINGA: ALTERNATIVE FOR THE FOOD SECURITY, CLIMATE RESILIENCE AND LIVELIHOOD IMPROVEMENT IN NEPAL." International Journal of Research - Granthaalayah, 8(3), 190-200. https://doi.org/10.29121/granthaalayah.v8.i3.2020.142.

\section{Introduction}

Moringa oleifera L. is a tree plant and it's native to India. However, it is widely grown in Africa, Pacific Islands, Caribbean, Philippines, South Africa, Asia, Florida, and Latin America (Fahey 2005). It is a fast-growing, multi-purpose, drought-tolerant and one of most useful tree because of its medicinal and nutritional properties in world and therefore globally described as a 'miracle tree' (Yishehak et al. 2011). It is reputedly known as "cabbage tree", 'drumstick tree" or "horseradish tree”, 'benzoil tree', 'miracle tree' and 'mother's best friend tree' (Koul \& Chawe 2015). It has multipurpose use, well adapted and significant economic importance, as it has vital nutritional, industrial, and medicinal applications (Dawit et al. 2016). It's all parts (leaves, fruits, immature 
pods, and flowers) are combined into the traditional food for human consumption (Sidhhuraju \& Becker 2003).

In Nepal the two-third of the population depends on agriculture to sustain livelihood which contributes about one third of national GDP (CBS 2011). The pressing challenge at present context is that agriculture has to be relied mostly upon women, children and senior citizen. Moringa can thus be an efficient commodity, as it is a hardy plant and doesn't demand stringent requirements. It is fast growing plant, well adapted to grow in adverse conditions where many other plants would not. Propagation through both sexual and asexual method (Paliwa et al. 2011), and well adaptive in broad ecological areas and less-intensive intercultural operation has proved its significance in livelihood uplift.

Livelihood has direct connection with climate change on all the assets (human, social, natural, physical and financial capital). Adaptation includes the activities like reducing poverty, improving access to resources, lowering inequities of resources and wealth, improving education, improving infrastructure, improving institutional capacity and efficiency and promoting local indigenous knowledge (Smit et al. 2001). As such, Moringa can be pivotal in solving both issues: related to climate change and livelihood. The carbon sinking attribute of Moringa can be utilized to curb the effect of global warming and at the mean time the problem of malnutrition, hunger, poverty, and unemployment could be addressed by promoting agri-business of Moringa in national and international level.

\section{Classification}

Kingdom - Plantae

Subkingdom - Tracheobionta

Superdivision - Spermatophyta

Division - Magnoliophyta

Class - Magnoliopsida

Subclass - Dilleniidae

Order - Capparales

Family - Moringaceae

Genus - Moringa

Species -Oleifera Lam.

(Source: USDA 2019)

\section{Distribution}

There are thirteen known species in the genus Moringa of family Moringaceae. These are Moringa oleifera, M. arborea, M. borziana, M. concanensis, $M$. drouhardii, M. hildebrandtii, M. longituba, M. ovalifolia, $M$. peregrine, $M$. pygmaea, $M$. rivae, $M$. ruspoliana and $M$. stenopetala.

Moringa arborea, $M$. borziana, $M$. longituba, $M$. pygmaea, $M$. rivae and $M$. ruspoliana are native to certain areas of Africa, and exist nowhere else in the world. Similarly, $M$. drouhardii and $M$. hildebrandtii are native to Madagascar. These two, along with M. ovalifolia and M. stenopetala, both native to parts of Africa, are called "bottle trees." M. oleifera L. can be distinguished by the stalked glands at the leaf base and rachis articulations; the three-valved fruits; the three-winged seeds and by a pungent horseradish odor from the leaves (FNAEC 2017). M. oleifera is found 
worldwide in the tropics and subtropics. The species is present in Asia, Africa, North America, Central America, the Caribbean, South America and Oceania.

M. oleifera L. is indigenous to northern foothills which includes Northern India, Pakistan and Nepal (Leone, et al. 2015). Much genetic diversity is especially available in the Tarai region of Nepal and India (Uttar Pradesh) (NPC 2006). Thus, M. oleifera has found wide acceptance, recognition and usefulness among the various ethnicities in different parts of Nepal. In Nepal, $M$. oleifera L. is cultivated in 13 different districts within the land area of 67 ha and 554 metric ton is produced every year (RDISPL 2072).

\section{Methodology}

This study is based on rigorous review of Moringa and related documents. It includes but is not limited to food security, climate change and livelihood convention related documents, national and international policies and strategies including plans and programmes, documents, published reports, journal articles, literatures and research papers. The information was drawn from national and international sources and they were critically scanned, skimmed, reviewed, shorted and analyzed for this study. This study was done from September 2018 to March 2019.

\section{Result and Discussion}

Moringa is a multipurpose tree and its each and every part has their use in human welfare and socio-cultural aspects. Their use and benefits are explained here under.

\section{General Use}

It can be said that there are multiple use of the Moringa in day to day life. Some of the use of the plant parts includes, but not limited to, uses like: alley cropping (bio-mass production), animal forage (leaves and treated seed cake), biogas (leaves), cleaning agent (crushed leaves), blue dye (wood), fencing (living trees), fertilizer (seed-cakes), foliar nutrient (leave juice), green manure (leaves), gum (tree trunk), honey and juice clarifier (powdered seed), honey (flower nectar), medicine (all plant parts), ornamental planting, bio-pesticide, rope (bark),tannin (bark and gum) (Fuglie 1999).

\section{Food and Nutritional Value of Moringa}

Moringa contains much more nutrient and medicinal chemical, and so, it is named as miracle tree plant. Moringa leaves contain more vitamin A than carrots, more Vitamin $\mathrm{C}$ than orange, more potassium than bananas, and on top of that the protein quality of Moringa leaves competes with that of milk and eggs (Fahey 2005).

Moringa tree is rich in nutrients such as minerals, fiber and proteins that can play essential role in human nutritional consumption. Numerous of the research reports have shown that Moringa oleifera leaves has high protein compared to with other leaves eaten as food (Suchada, Supawan, $\&$ Thanapat 2010). Each part of the Moringa tree (fruits, seeds, leaves, flowers, barks and roots) is associated with the presence of at least one, or in most number of benefits (Zaku et al. 2015). It have multiple uses i.e. leaves can be eaten fresh, cooked, or stored as dried powder for many months without loss of nutritional value. Till date, Moringa has seven use categories identified 
namely, medicine, food, fodder, fencing, firewood, coagulant and gum (Popoola \& Obembe 2013). Each part of the Moringa tree (fruits, seeds, leaves, flowers, bark and roots) is associated with the presence of at least one, or in most number of benefits (Zaku et al. 2015). The analysis of dietary iron supplements in the liver influenced by M. oleifera leaves revealed that iron from Moringa can overcome iron deficiency (Saini et al. 2014).

Table 1: Comparison of Moringa fresh and dry leaves with common foods per 100 grams

Source: Chukwuebuka 2015

\begin{tabular}{|l|l|c|c|}
\hline Nutrient & \multirow{2}{*}{ Common foods } & \multicolumn{2}{|c|}{ Moringa leaves } \\
\cline { 3 - 4 } & & Fresh leaves & Dried leaves \\
\hline Vitamin A & $1.8 \mathrm{mg}$ Carrots & $6.8 \mathrm{mg}$ & $18.9 \mathrm{mg}$ \\
\hline Calcium & $120 \mathrm{mg}$ Milk & $440 \mathrm{mg}$ & $2003 \mathrm{mg}$ \\
\hline Potassium & $88 \mathrm{mg}$ Banana & $259 \mathrm{mg}$ & $1324 \mathrm{mg}$ \\
\hline Protein & $3.1 \mathrm{~g}$ Yogurt & $6.7 \mathrm{mg}$ & $27.1 \mathrm{~g}$ \\
\hline Vitamin C & $30 \mathrm{mg}$ Orange & $220 \mathrm{mg}$ & $17.3 \mathrm{mg}$ \\
\hline
\end{tabular}

Besides, it has great use in culinary purpose. Wide varieties of dishes can be prepared from the parts of moringa, as a whole or mixed. In south Indian varieties, culinary items like sambars and fries are prepared from moringa pod. Likewise, it is used in curries, kormas and dal to enhance the taste; and at some place it is reported to be used in preparing cutlet dishes (Paliwa et al. 2011).

\section{Role in Ensuring Food Security and Hunger Alleviation}

In present global context, future of food security is in peril. There are about 30,000 edible plant species present of, only 30 are used to feed the world. As such, food security can only be assured by breaking the monoculture and promotion of neglected and underutilized crop species.

Food security is defined as achieving food security at the individual, household, national, regional and global levels when all people, at all times, have physical and economic access to sufficient, safe and nutritious food to meet their dietary needs and food preferences for an active and healthy life" (FAO 1996). The absolute number of undernourished people, i.e. those facing chronic food deprivation, has increased to nearly 821 million in 2017, from around 804 million in 2016 (FAO 2018). It is evident that among diverse availability of food crops, our world is dependent upon only few major crops and cereals; which have raised the issue of crop diversification.

In order to secure the future from food availability and nutrition, Moringa can be an effective crop species. Fresh Moringa leaves can be eaten raw, if they're very young and tender, but can be cooked as vegetable. Similarly, as a way to preserve nutrients leaf powder can also be made; this can be consumed as a whole food or added to other cooked food. Likewise, Moringa pod can be boiled, steamed, fried and eaten when they are young and tender and the seeds can also be consumed like other peas. It is also used in fortification of bread, biscuit, yoghurt, cheese, soup etc. (Oyeyinka \& Oyeyinka 2016). The inclusion of Moringa flower, seed or leaf powder in bread preparation has been reported to improve the nutritional value of bread (Chinma et al. 2012).

\section{Promising Source of Feed and Fodder}

Easy availability of fodder, vigorous growth and foraging nature, adaptability in climatically challenged land has increased the potential of Moringa plant as promising source of feed and 
fodder. Moringa can be used as a good source of ration for livestock. The high nutritional quality and better bio-mass production: especially in dry periods, supports in significance as livestock fodder (Nouman et al. 2014).

In a study, sunflower seed-cake was found possible to be replaced by Moringa Oleifera leaves as a conventional feed (Sarwatt et al. 2002). The cost advantage of Moringa can thus be a drive for engagement in animal husbandry. Similarly, a study concluded that Moringa leaf meal is well tolerated by the chicken, up to the level of $7.5 \%$ and can replace soybean meal in the broiler diet. Thus, significant impact on animal husbandry can be made using the feed and fodder from locally grown Moringa plant. It helps to reduce importing expensive feeds and also broaden the prospects in international trade by export of raw and processed materials.

\section{Medicinal Use}

Moringa is really a miracle plant that has wide range of medicinal uses. Moringa plant have several specific remedial properties including its anti-fibrotic, anti-inflammatory, anti-microbial, antihypoglycemic, anti-oxidant, anti-tumor and anti-cancer properties (Razis et al. 2014). Practically, most parts of the Moringa tree are utilized for some medicinal use which is presented in Table 2.

Table 2: Medicinal uses of different parts of Moringa plant

\begin{tabular}{|l|l|}
\hline Plant Part & \multicolumn{1}{|c|}{ Medicinal Use } \\
\hline Root & $\begin{array}{l}\text { Anti-lithic, rubefacient, vesicant, carminative, anti-fertility, anti-inflammatory, } \\
\text { stimulant in paralytic afflictions; act as a cardiac/circulatory tonic, used as a } \\
\text { laxative, abortifacient, treating rheumatism, inflammations, articular pains, } \\
\text { lower back or kidney pain and constipation }\end{array}$ \\
\hline Leaf & $\begin{array}{l}\text { Purgative, applied as poultice to sores, rubbed on the temples for headaches, } \\
\text { used for piles, fevers, sore throat, bronchitis, eye and ear infections, scurvy } \\
\text { and catarrh; leaf juice is believed to control glucose levels, applied to reduce } \\
\text { glandular swelling. }\end{array}$ \\
\hline Stem-bark & $\begin{array}{l}\text { Rubefacient, vesicant and used to cure eye diseases and for the treatment of } \\
\text { delirious patients, prevent enlargement of the spleen and formation of tuberculosis } \\
\text { glands of the neck, to destroy tumors and to heal ulcers. The juice from the root } \\
\text { bark is put into ears to relieve earaches and also placed in tooth cavity as a pain } \\
\text { killer, and has anti-tubercular activity. }\end{array}$ \\
\hline Flower & $\begin{array}{l}\text { High medicinal value as a stimulant, aphrodisiac, abortifacient, cholagogue; } \\
\text { used to cure inflammations ,muscle diseases, hysteria, tumors, and } \\
\text { enlargement of the spleen; lower the serum cholesterol, phospholipid, } \\
\text { triglyceride, VLDL, LDL cholesterol to phospholipid ratio and atherogenic } \\
\text { index; decrease lipid profile of liver, heart and aorta in hypercholesterolemia } \\
\text { rabbits and increased he excretion of fecal cholesterol. }\end{array}$ \\
\hline Seed & $\begin{array}{l}\text { Seed extract exerts its protective effect by decreasing liver lipid peroxides, } \\
\text { antihypertensive compounds thiocarbamate and is othiocyanate glycosides } \\
\text { have been isolated from the acetate phase of the ethanolic extract of Moringa } \\
\text { pods. }\end{array}$ \\
\hline
\end{tabular}

Source (Farooq et al. 2006) 
Moringa has been used in the traditional medicine passed down for centuries in many cultures around the word, for skin infections, anemia, anxiety, asthma, blackheads, blood impurities, bronchitis, catarrh, chest congestion, cholera, conjunctivitis, cough, diarrhea, eye and ear infections, fever, glandular, swelling, headaches, abnormal blood pressure, hysteria, pain in joints, pimples, psoriasis, respiratory disorders, scurvy, semen deficiency, sore throat, sprain, tuberculosis, for intestinal worms, lactation, diabetes and pregnancy (Nikkon et al 2003).

\section{Measure to Curb Global Warming and Climate Change}

Climate change is a pressing issue at present and not only for farmers but its effect is a matter of concern for all. The role of farmers and forest user is however pivotal to reduce climate change. The adaptation strategies and plan to cope and curb the climate change impacts is thus required (Gedefaw 2015). In developing country like Nepal, rather than innovating sophisticated measures, it is judicial to look up the available solution which have not been explored. Moringa can thus be efficient tool in this context, due to its invincible attributes like hardiness and adaptation on various environmental variations.

Moringa and its bushes can survive well even in the dry climate. The wood absorbs atmospheric carbon dioxide and sequestrates it and thus helps to curb global warming. The rate of assimilation of $\mathrm{CO}_{2}$ is higher than that in other plants. In a study, when the rate of absorption $\mathrm{CO}_{2}$ of Moringa and Japanese cedar was compared, Moringa was found fifty fold higher. Similarly, comparing with the normal vegetation it was twenty rimes higher (Daba 2016). From another study, it was also found that, for the total $320 \mathrm{~kg}$ of carbon dioxide emitted from a person per year, it requires 23 Japanese cedar trees a year of 50 years but in case of Moringa, 2 Moringa trees just takes 2 years to absorb that amount.

In the face of climate change and variability, the standing tree of Moringa Oleifera can thus act as reservoir of carbon dioxide and reduce the extent of global warming. Also, it helps to sustain biodiversity in adverse climatic condition. It helps to control soil erosion, wind speed and wild animals by fencing.

Moringa As Bio-Fertilizer and Plant Supplement

Moringa has an immense potential as fertilizer supplement for plants. Analysis of plant data proves it to be a good nutrient carrier, containing nutrient elements that can enhance effective and productive cultivation of crops, while in-turn maintaining soil fertility status (Adiaha 2017).

Similarly, in one study, Moringa extract was found to increase growth and yield of tomato in both greenhouse and field. It was found that its extract significantly increased above ground dry matter yield (DM), root dry matter weight and plant height for the crop (Culver, Fanuel, \& Chiteka 2012). Similarly, Moringa leaf extract was found to improve fruit set, yield, fruit weight, firmness, color, soluble solids content, vitamin C, anthocyanin content and antioxidant activity of "Hollywood" plum (Thanaa et al. 2017).

Exogenous application of Moringa leaf extract, whether it is an aqueous or ethanol extract, improves productivity in many crops, because Moringa leaf extract possesses great antioxidant activity and is rich in plant secondary metabolites such as ascorbic acid and total phenols, making it a potential natural growth stimulant (Yasmeen et al. 2012). 
Thus, self-reinforcing nature of Moringa i.e. standing plant utilizing nutrients from less potential soil and its extract replenishing the nutrient is beneficial in agricultural land.

\section{Moringa For Soil Reclamation}

It has been found that Moringa have metal binding properties and can help remove several contaminants from aqueous solutions. It also possesses strong anti-coagulant properties like 'Alum' that can remedify contaminated water (Sinha et al. 2009). Moringa seed extract removes heavy metal ions from the soil at pH levels of 6 to 8 (Sajidu et al. 2006).

Thus, in the marginalized land, Moringa can be cultivated at low cost to ensure its fertility. Similarly, in a study on application of Moringa leaf extract on root development and yield of Soybean (Glycine max), physio-chemical properties of the soil were found to be improved. Also, the result suggested soil application of Moringa leaf extract as soil exogenous nutrient could enhance growth process and leads to increase mineralization of nutrient (Asagwara \& Emeribe 2017). Likewise, Moring a oleifera seeds have been shown to remove arsenic from water (Kumari et al. 2006).

Hence, it is evident that the marginalized land and degraded land can be effectively utilized, and in turns be transformed to cultivable land for other major crops later.

\section{Socio-Cultural Aspects and Prosperity}

In socio-economic consideration, Moringa is a promising plant. It helps to battle malnutrition and hunger, and also provides employment of social relevance. Farm and nurseries could be established even in a drought regime, and social institution in return gets benefited from it. In one hand, food secure society operates in harmony and on other hand, trade and business of same product help to prosper the economy. Thus, Moringa can be used as an effective tool in uplifting local communities, promoting social responsibility and encouraging social integrity.

Unlike mainstream crops, it doesn't require intensive care - home made compost and manure application with sporadic irrigation just to make the soil wet is sufficient for optimum result. It can be grown under high-density monoculture, or intercropped with other crops. Flooded land, dry river bed or waste land which is otherwise unused could be utilized for Moringa plantation and hence, even the marginalized people can get benefitted. In Nepal, Moringa can be attributed to cultural values as well. In the second day of the Nepalese New Year, sacred water is sprinkled as a symbolic relief from the upcoming summer and Moringa vegetable is consumed for the same purpose, and the day celebrated as Moringa Day. It thus helps to maintain cultural integrity and social well-being.

Thus, Moringa can help to create a well-nourished, healthy individual with happy family engaged in agriculture and agro-forestry blessed with good return and food-security. Therefore, Moringa cultivation can be envisaged as a precursor of prosperity.

As economic value, this tree leaves can be processed and marketed in different forms like Moringa tea, Moringa powder, moinga juice, Moringa capsule, Moringa pellete, etc. It's leaves used in kitchen as many recipe such as pakauda, sag, amlet, bada and powder in fish and meat items. The leaves are also used for feed and fodder of fish, poultry, pigs, goat and cattle, which gives farmers 
more benefit from different enterprises. The sticks can be sold as vegetable in the market at off and on season at higher price. The oil and oil cake from seed can be prepared and sold for various cosmetic and medicinal purposes. This is the one of the high value crops for poor and vulnerable families too. The most nutritive, fast growing, hardy, easily propagated, medicinal use, ecofriendly and economically profitable nature of Moringa, the tree crop serves as boon for poor country like Nepal. The higher productivity of leaves and pods fetches higher income for farmers, traders, processer and retailers. Considering these points, Climate change adaptation in Agriculture sector of FAO, Heifer Nepal, soil conservation office, and other projects and programmes have promoted Moringa planation in project area.

\section{Conclusion}

Moringa oleifera $L$. is a plant native to India but it is widely grown tree in Africa, Pacific Islands, Caribbean, Philippines, South Africa, Asia, Florida and Latin America. It is a drought-tolerant, fast-growing, multi-purpose, eco- friendly and one of most useful tree due to its medicinal and nutritional properties in world and therefore described as a 'miracle tree'. Moringa tree is rich in nutrients such as vitamins, minerals, fiber and proteins that. It is a very nutritious plant containing more vitamin $\mathrm{A}$ than carrots, more Vitamin $\mathrm{C}$ than orange, more potassium than bananas, and protein quality of leaves competing with that of milk and eggs. Hence, it can play essential role in human nutritional consumption. Moringa has wide range of medicinal uses as anti-fibrotic, antiinflammatory, anti-microbial, anti-hypoglycemic, anti-oxidant, anti-tumor and anti-cancer properties.

Fresh Moringa leaves can be used in vegetables. Leaf powder can also be consumed as food, nutrient supplement and medicinal purpose. The tender pods can be consumed as boiled, steamed, and fried and the seeds can also be consumed like peas. Moringa can be effective in assuring food security be by breaking the monoculture and also promote promotion of other neglected and underutilized crop species.

Moringa can be used as a good source of animal and bird feeds due to its nutritional quality and better bio-mass production especially in dry periods. Similarly, its leaf extract was found to improve fruit set, yield, fruit weight, firmness, color, soluble solids content, vitamin C, anthocyanin content and antioxidant activity. Thus, Self-reinforcing nature of Moringa from less potential soil and its extract replenishing the nutrient is beneficial in agricultural land.

The most alarming challenge, like climate change and global warming, for country like Nepal, it is judicial to look up the available solution which has not been explored. As such, due to its hardiness and adaptation on various environmental variations, Moringa can be an efficient commodity. Its wood also absorbs atmospheric carbon dioxide and sequestrates them and thus helps to curb global warming. Nepal, with one fourth of population under the poverty line and being highly vulnerable to climate change, has wide scope for Moringa plantation for their livelihood improvement. Till date, in Nepal not much research has been done on Moringa cultivation. Imminent threats from food security, malnutrition, climate change and livelihood quality decline could be addressed if immediate initiation for systematic and scientific research as well as promotion of the Moringa is done at different agro-climatic regions of Nepal. 


\section{Acknowledgement}

We would like to express our sincere appreciation to the Ministry of Agriculture and Livestock Development, FAO of United Nations, climate change adaptation in agriculture sector project for giving us the opportunity to use information. We thank Dr. Binod Shah, Assistant FAO Representative of FAO, Mr. Arjun Singh Thapa, Programme officer FAO, Dr. Krishna Prasad Pant, National Technical Coordinator of FAO, CCA project for his kind support and cooperation. We also thank to FAO, CCA project field team for coordinating livelihood support activities.

\section{References}

[1] Adiaha MS, 2017. Petential of Moringa oleifera as nutrient-agent for biofertilizer production. World News of Natural Sciences, pp. 101-104.

[2] Agbogidi O \&Llondu E, 2012. Moringa oleifera Lam: its potentials as a food Moringaoleifera Lam: its potentials as a food. J Bio Innov, p. 1: 156-167.

[3] Arora DS, Onsare JG \& Kaur H. 2013. Bioprospecting of Moringa (Moringaceae): Microbiological perspective. J pharmacogandphytochem, pp. 1: 193-215.

[4] Asagwara JO. \&Emeribe E. 2017. Soil Application of Moringa Leaf Extract on Root Development and Root Exudates of Soybean (Glycine max L.). International Journal of Agriculture Innovations and Research, pp. Volume 6, Issue 2.

[5] CBS. 2011. Cenral Bureau of Statistics of Nepal, Kathmandu: National Planning Commission Secretariat.

[6] Chinma CE, Abu JO \&Akoma JN. 2012. Effect of germinated Moringa and Tigernut flour blends on the quality of wheat-based bread.Journal of food processing and preservation.

[7] Chukwuebuka E. 2015. Moringaoleifera"The Mother's Best Friend". International Journal of Nutrition and Food Sciences, pp. Vol: 4, No: 6, Page:624-630.

[8] Culver M, Fanuel T \&Chiteka AZ. 2012. Effect of Moringa extract on growth and yield of tomato. Greener Journal of Agricultural Science, pp. 207-211.

[9] Daba M. 2016. Miracle Tree: A Review on Multi-purposes of Moringa oleifera and Its Implication for Climate Change Mitigation. Journal of Earth Science \& Climatic Change, p. 7:366.

[10] Dawit S, Regassa T, Mezgebu S \&Mekonnen D. 2016. Evaluation of two Moringa species for adaptability and growth performance under Bako conditions. J Natural Sciences Research, pp. 6: 76-82.

[11] Fahey J. 2005. Moringa oleifera: A review of the medical evidence for its nutritional, therapeutic and prophylactic properties. Trees for Life Journal, p. 1: 5.

[12] FAO. 1996. Rome declaration on world food security and world food. Rome, Food and Agriculture Organization of United Nations.

[13] FAO. 2018. The State of Food Security and Nutrition in the World: Building climate resilience for food security and nutrition, Rome: Food and Agriculture Organization of United nations.

[14] Farooq A, Latif S, Ashraf M. \&Gilani AH. 2006. Moringa oleifera: A Food Plant with Multiple Medicinal Uses, 21:17-25: Phytother.Res.

[15] FNAEC. 2017. Flora of North America Editorial Committee. 2016. Flora of North America North of Mexico. St. Louis, Missouri and Cambridge, Massachusetts, USA: Missouri Botanical Garden and Harvard University Herbaria. http://www.efloras.org/flora_page.aspx flora_id1

[16] Fuglie LJ. 1999. The Miracle Tree: Moringa oleifera : Natural Nutrient for the Tropics. Dakar: Church World Service.

[17] Gakuya DW, Mbuya PN, Kavoi B \&Kiama SG. 2014. Effect of supplementation of Moringa oleifera leaf meal in broiler-chicken feed. International Journal of Poultry Science, pp. 208-213. 
[18] Gedefaw M. 2015. Environmental and Medicinal value analysis of Moringa (Moringa oleifera) tree species in Sanja, North Gondar, Ethiopia. AIJCSR-480, pp. 2: 20-35.

[19] Koul B \&Chawe N. 2015. Moringa oleifera Lam.: Panacea to several maladies. Journal of Chemical and Pharmaceutical Research, pp. 7:687-707.

[20] Kumari P, Sharma P, Srivastava S \& Srivastava M. 2006. Biosorption studies on shelled Moringa oleifera Lamarck seed powder: Removal and recovery of arsenic from aqueous system. Int. J. Miner. Process, pp. 78, 131-139.

[21] Leone A, Spada A, Battezzati A, Schiraldi A, Aristil J \& Bertoli S (2015). Cultivation, Genetic, Ethnopharmacology, Phytochemistry and Pharmacology of Moringa oleifera Leaves: An Overview. International journal of molecular sciences, 16(6), 12791-12835. doi:10.3390/ijms 160612791

[22] National Research Council. 2006. Lost Crops of Africa: Volume II: Vegetables. Washington, DC: The National Academies Press. https://doi.org/10.17226/11763.

[23] Nikkon, F, Saud ZA, Rahman MH \&Haque ME. 2003. In vitro antimicrobial activity of the compound isolated from chloroform extract of Moringa oleifera Lam. Pak. J. Biol. Sci., pp. 6: 18881890 .

[24] Nouman W et al. 2014. Potential of Moringa oleifera L. as livestock fodder crop: A review. Turkish Journal of Agriculture and Forestry, pp. 8(1):1-14.

[25] Oyeyinka AT \&Oyeyinka SA. 2016. Moringa oleifera as a food fortificant: Recent trends and prospects. Journal of Saudi Society of Agricultural Science, pp. 127-136.

[26] Paliwal R, Sharma V \&Pracheta .2011. A Review on Horse Radish Tree (Moringa oleifera): A Multipurpose Tree with High Economic and Commercial Importance. Asian J. of Biotech, Vol.3(4) pp317-328

[27] Popoola J \&Obembe O. 2013. Local knowledge, use pattern and geographical distribution of Moringa oleifera Lam. (Moringaceae) in Nigeria. J. of Ethnopharma, pp. 150:682-691.

[28] Ramachandran C, Peter KV. And Gopalakrishnan PK. 1980. Drumstick (Moringa oleifera): A multipurpose lndian vegetable. Economic Botany 34:276-283

[29] R\&D Innovative Solution Pvt. Ltd. 2015. Krishak ra Prabidhi. edition 7, pg 10

[30] Retrieved from www.agrinepal.com.np

[31] Razis AFA, Ibrahim MD \&Kntayya SB. 2014. Health Benefits of Moringaoleifera. Asian Pacific journal of cancer prevention: APJCP, pp. 15(20):8571-6.

[32] Saini R et al. 2014. Dietary iron supplements and Moringaoleifera leaves influence the liver hepcidinmessenger RNA expression and biochemical indices of iron status in rats. NutrRes, p. 34: 630-638.

[33] Sajidu S, Henry E, Kwamdera G \&Mataka L. 2006. Removal of lead, iron and cadmium ions by means of polyelectrolytes of the Moringa oleifera whole seed kernel. WIT Trans. Ecol. Environ, pp. 80, 1-8.

[34] Sarwatt SV, Kapange SS \&Kakengi A. 2002. Substituting sunflower seed-cake with Moringa oleifera leaves as a supplemental goat feed in Tanzania. Agroforestry Systems, pp. Vol 56(3), Page 241.

[35] Sidhhuraju P \& Becker K. 2003. Antioxidant properties of various solvent extracts of total phenolic constituents from three different agro-climatic origins of drumstick tree (Moringa oleifera Lam.). J Agri Food Chem, p. 15: 2144-2155.

[36] Sinha RK et al. 2009. Bioremediation of contaminated sites: a low-cost nature's biotechnology for environmental clean up by versatile microbes, plants \& earthworms. In: solid waste management and environmental remediation. New York: Nova Science Publishers, Inc.

[37] Smit B et al. 2001. Adaptation to climate change in the context of sustainable development and equity: Climate Change 2001: Impacts, Adaptation, and Vulnerability. New York: Cambridge University Press. 
[38] Suchada J, Supawan B \&Thanapat S. 2010. Nutrients and Minerals Content of Eleven Different Samples of MoringaOleifera Cultivated in Thialand. J Health RES, p. 24: 123-127.

[39] Thanaa S, Kassim NE, AbouRayya MS \&Abdalla AM. 2017. Influence of Foliar Application with Moringa (Moringaoleifera L.) Leaf Extract on Yield and Fruit Quality of Hollywood Plum Cultivar. Journal of Horticulture, p. 4:193.

[40] USDA.2019. Natural Resource Conservation Service. Retrieved from United State Department of Agriculture: https://plants.usda.gov/java/ClassificationServlet?source=display\&classid MOOL

[41] Villafuerte LR \&Villafurte-Abonal L. 2009. Data taken from the Forestry Agency. MalunggayPhillippines, Apples of Gold Publishing, p. P 240.

[42] Yasmeen A, Basra S, Ahmad R \& Wahid A. 2012. Performance of late sown wheat in response to foliar application of Moringaoleifera Lam. leaf extract. Chil. J. Agric. Res, pp. 2, 92-97.

[43] Yishehak K, Solomon M \&Tadelle M. 2011. Contribution of Moringa (Moringastenopetala, Bac.), a Highly Nutritious Vegetable Tree, for Food Security in South Ethiopia: A Review. Asian J Applied Sciences, pp. 4: 477-488.

[44] Zaku SG, Tukur S \& Kabir A. 2015. Moringa oleifera: An underutilized tree in Nigeria with amazing versatility. African Journal of Food Science, pp. 9(9) 456-461.

*Corresponding author.

E-mail address: shreebhag avanthakur@gmail.com/bajagainakash@gmail.com 